\title{
POLA BANGUNAN LEUIT, SAUNG LISUNG, DAN GOAH PADA MASYARAKAT SUNDA KASEPUHAN CIPTAGELAR
}

\author{
Afina Nisa Aulia, Gregorius Prasetyo Adhitama \\ (afinanisa146@gmail.com,gregoriusprasetyoadhitama@gmail.com) \\ Program Studi Desain Interior \\ Fakultas Seni Rupa dan Desain \\ Institut Teknologi Bandung \\ Jl. Ganesha No. 10. Lb Siliwangi, Kecamatan Coblong, Kota Bandung, Indonesia
}

\begin{abstract}
ABSTRAK
Sebagai masyarakat peladang yang masih menerapkan aturan leluhur, masyarakat Sunda Kasepuhan Ciptagelar memiliki aturan tersendiri terkait pengolahan pangan, dimulai dari menyimpan padi di leuit (lumbung), menumbuk padi di saung lisung, hingga memasak nasi di goah (area masak). Tidak hanya itu, masyarakat ini juga tidak pernah kekurangan pangan, bahkan memiliki persediaan pangan yang cukup hingga beberapa tahun kedepan. Sehingga tujuan utama dari penelitian ini adalah untuk melihat keterkaitan penggunaan leuit, saung lisung, dan goah, terutama dari pola bangunan, dalam budaya bertani masyarakat Sunda Kasepuhan Ciptagelar sebagai upaya menjaga ketahanan pangan. Adapun budaya masyarakat terkait penelitian ini adalah: tilu sapamilu (falsafah hidup), tatali paranti karuhun (kepercayaan adat), serta pemerintahan adat. Berdasarkan tujuan tersebut, maka penelitian ini termasuk ke dalam penelitian etnografi dengan metode penelitian kualitatif. Data dalam penelitian ini diperoleh dari hasil observasi site-plan kampung adat Sunda Kasepuhan Ciptagelar, jarak antar bangunan, jumlah bangunan secara keseluruhan, serta data literatur yang mendukung. Setelahnya data dianalisis menggunakan teori Ruang dan Jarak Relph yang menyatakan bahwa jarak tiap bangunan merepresentasikan identitas dan maknanya sendiri yang didasari oleh pemahaman manusia mengenai ruang atau jarak dari lingkungan yang dihuni. Analisis mengenai posisi dan jarak bangunan ini kemudian dikaitkan dengan keberhasilan pengelolaan pangan masyarakat Kasepuhan Ciptagelar dengan menggunakan metoda analisis interpretatif. Hasil penelitian menemukan bahwa keseluruhan desa Kasepuhan Ciptagelar merupakan area yang luas sehingga terbagi menjadi beberapa klaster bangunan yang saling terpisah dengan jarak yang cukup jauh satu sama lain. Meskipun begitu, dikarenakan ketiga obyek penelitian ini merupakan satu kesatuan yang terintegrasi hingga tidak dapat dipisahkan, maka ketiganya akan selalu ada di tiap klaster yang paling kecil dan terisolir sekalipun. Dengan demikian, tiap klaster memiliki setidaknya satu komplek leuit tempat menyimpan padi, satu saung lisung tempat menumbuk padi, dan masing-masing rumah memiliki goah tempat memasak beras. Adanya ketiga jenis bangunan ini menjadikan tiap klaster berdaulat dalam hal pangan dimana mereka masing-masing memiliki fasilitas untuk menyimpan padi, menumbuk padi, dan memasak nasi.
\end{abstract}

Kata Kunci: Jarak; Leuit; Saung lisung; Goah; Sunda Kasepuhan Ciptagelar

\section{ABSTRACT}


As a farming community who still applies ancestral rules, the Sundanese Kasepuhan Ciptagelar people have their own rules regarding food processing, starting from storing rice in the leuit (barn), pounding rice in saung lisung, to cooking rice in goah (cooking area). This community also never lacks food, even has sufficient food supplies for the next few years, which is why the main objective of this research is to see the link between the use of leuit, saung lisung, and goah, especially from building patterns, in the farming culture of the Sundanese Kasepuhan Ciptagelar community as an effort to maintain food security. The community culture associated are: tilu sapamilu (philosophy of life), tatali paranti karuhun (customary beliefs), and customary governance. Based on these objectives, this research use a qualitative research approach with the ethnography inquiry. The data were obtained from the results of site-plan observations of the Sundanese Kasepuhan Ciptagelar traditional village, the distance between buildings, the total number of buildings, and supporting literature data. The data then analyzed using Relph's theory of Space and Distance, which states that the distance of each building represents its own identity and meaning which is based on human understanding of space or the distance from the inhabited environment. The analysis of the position and distance of the building was then linked to the success of the food management of the Kasepuhan Ciptagelar community using the interpretive analysis method. The analysis was also using cultural elements of the Sundanese Kasepuhan Ciptagelar people, namely: tilu sapamilu (philosophy of life), tatali paranti karuhun (customary beliefs), and customary government. The results of the study found the entire Kasepuhan Ciptagelar village is such a large area, so that it is divided into several building clusters which are quite far apart from each other. Even so, because the three objects of this research are an integrated unit that cannot be separated, they will always exist in each of the smallest and most isolated clusters. Thus, each cluster has at least one leuit complex where rice is stored, one saung lisung for pounding rice, and each house has a goah for cooking rice. The existence of these three types of buildings makes each cluster sovereign in terms of food where they each have facilities to store, pound, and cook rice.

Keywords: Distance; Leuit; Saung lisung; Goah; Sunda Kasepuhan Ciptagelar

\section{PENDAHULUAN}

Masyarakat Sunda Kasepuhan memiliki aturan ketat terkait proses pengolahan padi dan beras, dimulai dari aturan menanam padi sekali dalam setahun, menggunakan padi jenis lokal, memanen pada waktunya, menyimpannya di lumbung padi (leuit), mengambil padi untuk ditumbuk di saung lisung, dan membawanya ke dapur (pawon) untuk kemudian dimasak di tungku (hawu) dan dikonsumsi (Nuryanto, 2011). Kenyataan bahwa masyarakat Sunda Kasepuhan tidak pernah mengalami kelaparan berkepanjangan atau kekurangan padi untuk tiap warganya membuktikan bahwa masyarakat ini memiliki strategi yang cerdik dalam hal pengelolaan pangan (Ambayoen dkk, 2018). Pemahaman inilah yang kemudian menjadi dasar dilakukannya penelitian, yakni untuk mengidentifikasi dan menganalisis bagaimana tepatnya strategi yang dilakukan oleh masyarakat Sunda Kasepuhan dalam mengelola pangan, terutama dari sisi pola bangunan desain tradisional yang digunakan. 
Ketua Adat atau Sepuh Girang dari Sunda Kasepuhan Ciptagelar, Ugi Sugriwa Raka Siwi, yang memiliki gelar Abah ini mempersilakan warganya untuk menikmati teknologi modern seperti televisi, telepon genggam, dan lain sebagainya. Selama teknologi tersebut tidak mengganggu adat istiadat leluhur maka tidak ada salahnya bagi masyarakat Sunda Kasepuhan Ciptagelar untuk mempelajari dan menikmati kecanggihan teknologi. Satu hal yang sama sekali tidak boleh berubah adalah proses terkait padi dan beras, dimulai dari proses menanam padi hingga menumbuknya menjadi beras. Bagi masyarakat ini, sistem pengolahan padi merupakan hal yang sakral dan tidak boleh diubah atau diganti dengan barang-barang elektronik. Begitupula dengan sistem panen padi, penyimpanan padi ke lumbung, hingga proses penumbukan padi menjadi beras. Selain itu, masyarakat Sunda Kasepuhan juga dilarang keras untuk menjual padi atau beras karena menganggap bahwa padi atau beras merupakan bagian dari kehidupan sehingga menjualnya sama artinya dengan menjual kehidupan atau nyawa itu sendiri, demikian penjelasan dari juru bicara Sunda Kasepuhan Ciptagelar, Yoyo Yogasmana (Pikiran Rakyat, 2017).

Dalam kehidupan sehari-hari, masyarakat Sunda Kasepuhan masih terus mempertahankan ajaran leluhur yang mereka percayai sejak jaman nenek moyang mereka yaitu tatali paranti karuhun. Menurut Asep (2000), tatali paranti karuhun kurang lebih berarti mengikuti, mentaati, dan mematuhi cara menjalani kehidupan sebagaimana yang dilakukan oleh para leluhur (karuhun). Tatali paranti karuhun itu sendiri berasal dari kata tali dalam bahasa Sunda, dimana bagi masyarakat Sunda, tali tersebut digunakan sebagai pengikat dan pengukur sehingga secara simbolis melambangkan suatu keterikatan dan ukuran dalam menjalani kehidupan hingga kembali ke asal (dunia akhirat). Hal ini menyebabkan tatali paranti karuhun sebagai sesuatu yang sakral dan harus ditaati sehingga siapapun yang tidak mengikutinya dianggap celaka (kabendon) dan akan membawa malapetaka tidak hanya bagi dirinya sendiri, tetapi juga bagi seluruh warga masyarakat Kasepuhan (Asep, 2000).

Penelitian terkait strategi pengelolaan pangan masyarakat Sunda tradisional telah dilakukan sebelumnya, yakni oleh Mas Ayu Ambayoen, dkk. pada tahun 2018 dengan judul penelitian Communication Strategy of Kasepuhan Sinar Resmi Community In Maintaining Local Varieties For Strengthening Leuit (Village Barns) dan Bambang Darjanto pada tahun 2015 dengan judul penelitian Pola Tanam Padi Dan Dampaknya Terhadap Ketahanan 
Pangan Pokok (Studi Pada Masyarakat Adat Banten Kidul Kasepuhan Ciptagelar Di Desa Sirnaresmi Kecamatan Cisolok Kabupaten Sukabumi). Hasil dari penelitian oleh Ambayoen dkk (2018) menunjukkan bahwa strategi pangan masyarakat Sunda Kaspuhan adalah melalui sistem komunikasi yang dilakukan oleh pemerintahan adat yang memerintahkan warga untuk tetap mengolah padi dan beras sesuai dengan ajaran luhur, diantaranya adalah menanam sesuai aturan luhur serta larangan dan anjuran terkait padi. Sementara hasil penelitian Darjanto (2015) menunjukkan bahwa ketahanan pangan masyarakat Sunda Kasepuhan didasari oleh pola tanam padi sekali setahun sesuai ajaran luhur yang menciptakan keseimbangan antara manusia, tuhan, dan alam. Ajaran luhur ini juga mengatur kebijakan terkait pangan, seperti waktu penanaman padi, penggunaan bibit lokal, melarang penjualan padi hasil produksi masyarakat Kasepuhan menjaga dan memanfaatkan sumber air untuk masyarakat dan pertanian.

Berdasarkan dua penelitian tersebut diatas dapat disimpulkan bahwa strategi yang dilakukan untuk mempertahankan kedaulatan pangan adalah ketekunan masyarakat ini dalam melaksanakan perintah luhur, terutama dalam bidang pangan seperti tata cara tanam padi yang sesuai dengan ajaran nenek moyang dan usaha Ketua Adat dalam mensosialisasikan ajaran nenek moyang tersebut melalui jalur komunikasi. Akan tetapi belum dijelaskan secara mendetail bagaimanakah aturan tradisi tersebut berkonstribusi dalam kesehariannya, terutama penjelasan bagaimana pola bangunan tradisional leuit, saung lisung, dan goah ikut berpartisipasi dalam upaya menjaga ketahanan pangan.

Adapun teori yang digunakan dalam penelitian kali ini adalah teori Ruang dan Jarak yang digagas oleh Edward Relph (1976), dimana yang menyatakan bahwa jarak tiap bangunan merepresentasikan identitas dan maknanya sendiri, dimana suatu ruang dan tempat terstruktur secara dialektik dalam pengalaman lingkungan manusia, dikarenakan pemahaman manusia berkaitan erat dengan tempat yang dihuni.

Dalam analisis, tahapan yang dilakukan diawali dengan sajian data kolektif yang didapat hasil dari obervasi lapangan. Dikarenakan tujuan utama penelitian ini adalah hubungan antara pola bangunan leuit, saung lisung, dan goah dengan ketahanan pangan masyarakat Sunda Kasepuhan Ciptagelar, maka data jarak antar bangunan disajikan dalam bentuk siteplan. Setelahnya site-plan ini dibagi menjadi klaster-klaster kecil yang merupakan kumpulan dari komplek perumahan, saung lisung, dan leuit agar mempermudah membaca 
makna dari eksistensi bangunan serta perannya dalam upaya yang dilakukan oleh masyarakat Sunda Kasepuhan dalam menjaga ketahanan pangan. Adapun cara pembagian klaster-klaster dalam site-plan tersebut adalah dengan mengelompokkan satu area hunian tiap warga yang didasari oleh kepemilikan bangunan tersebut (leuit, saung lisung, dan goah) serta pemakaian bangunan tersebut terkait proses pengolahan pangan. Setelahnya klasterklaster tersebut didata terkait jarak antar klaster dan bangunan di tiap klaster, untuk kemudian dianalisis dengan menggunakan teori Ruang dan Jarak Relph serta dikaitkan dengan elemen kebudayaan Sunda Kasepuhan, yaitu falsafah hidup (tilu sapamilu), kepercayaan (tatali paranti karuhun), dan sistem pemerintahan adat (Sesepuh Girang). Penentuan elemen budaya yang dipilih untuk menganalisis makna pola bangunan ini didasari oleh teori yang digunakan serta ciri dari kemandirian atau kedaulatan pangan, yakni:

1) Teori Ruang dan Jarak

Dalam upaya untuk memahami makna dari satu jarak antar bangunan, perlu diketahui pandangan masyarakat tersebut terhadap artefak tersebut baik berdasarkan religi maupun berdasarkan aktivitas di dalamnya (Relph, 1976), karenanya diambillah elemen budaya falsafah hidup (tilu sapamilu) dan kepercayaan (tatali paranti karuhun)

2) Ciri kedaulatan pangan

Ciri atau indikasi dari kedaulatan pangan adalah tersedianya pangan yang terjangkau baik harga maupun jaraknya, serta adanya antisipasi dari pihak pemerintah. Dengan demikian diambil elemen sistem pemerintahan (Sesepuh Girang) untuk melihat adakah keterlibatan pemerintah Kasepuhan Ciptagelar dengan kedaulatan pangan masyarakat ini.

\section{METODE PENELITIAN}

Menurut Creswell dan Poth (2016), terdapat 5 strategi dalam penelitian kualitatif, yakni: naratif, fenomenologi, studi kasus, etnografi, dan teori dasar. Adapun strategi yang digunakan dalam penelitian kali ini adalah etnografi dengan pendekatan kualitatif dimana data diperoleh dari observasi partisipasi, wawancara mendalam, dokumentasi, serta studi literatur. Validasi internal didapat dengan cara triangulasi data dengan cara observasi berulang dan wawancara mendalam dengan ahli budaya di Kasepuhan Ciptagelar. Berikut ini penjelasan lebih lanjut mengenai tahapan atau metode yang dilakukan dalam penelitian. 
Sebagaimana yang telah dijelaskan sebelumnya, penelitian ini bertujuan untuk memahami arti dari pola bangunan leuit, saung lisung, dan goah yang sesuai dengan budaya bertani masyarakat Sunda tradisional ini, dan bagaimana pengaturan pola ini berperan dalam upaya masyarakat tersebut menjaga ketahanan pangan. Berdasarkan pemahaman inilah penelitian kali ini dibatasi: 1) Di lingkup masyarakat Sunda yang masih menerapkan nilainilai tradisi, salah satunya adalah Sunda Kasepuhan Ciptagelar, yang berlokasi di Pegunungan Halimun, Kabupaten Sukabumi, Jawa Barat; dan 2) Fokus pada jarak antar bangunan terkait budaya bertani masyarakat atas proses pengolahan padi beserta pola yang dimiliki, yakni leuit, saung lisung, dan goah. Berikut adalah tahapan metode pengumpulan data dalam penelitian:

1) Metodologi kualitatif, perlu dilakukan studi literatur (kaji pustaka) untuk memahami perihal ketahanan pangan dan mengetahui latar belakang budaya masyarakat Sunda Kasepuhan Ciptagelar.

2) Penelitian etnografi, sebagaimana yang dijelaskan oleh Manan (2015), teknik pengambilan data dalam penelitian ini adalah dengan cara:

a. Observasi partisipasi

Melakukan observasi langsung di Kampung Gede Sunda Kasepuhan Ciptagelar, Desa Sirnaresmi kecamatan Cisolok, kabupaten Sukabumi, Jawa Barat.

b. Wawancara mendalam

Wawancara dilakukan pada Aki Karma, selaku ahli adat di bidang pertanian atau Dukun Tani, yang termasuk dalam Baris Kolot atau jajaran pemerintahan di Sunda Kasepuhan Ciptagelar. Wawancara juga dilakukan pada beberapa warga lain yang mendukung pernyataan yang dijelaskan. Wawancara yang dilakukan bersifat wawancara tak terstruktur.

c. Dokumentasi

Dokumentasi berupa foto dan video terkait jarak ketiga bangunan di Kampung Gede Kasepuhan Ciptagelar.

\section{PEMBAHASAN}

\section{A. Hasil Observasi dan Data Literatur}


Sebelum memulai pembahasan terkait makna jarak bangunan, perlu dipahami apa yang dimaksud dengan ketahanan pangan itu sendiri. Strategi pengelolaan pangan atau sistem pangan adalah satu bentuk upaya yang dilakukan untuk terpenuhinya kebutuhan pangan yang cukup dan sesuai bagi manusia. Ariesa (2019) dalam jurnalnya menyatakan ketahanan pangan dapat dikatakan terpenuhi jika memenuhi kriteria: 1) tersedianya pangan yang cukup, mencakup produk hewani dan nabati; 2) terpenuhinya pangan yang aman, dalam arti bebas dari pencemaran yang berbahaya; 3) terpenuhinya pangan secara merata, dimana pangan dapat diakses dan diterima oleh seluruh masyarakat; dan 4) terpenuhinya pangan dengan harga terjangkau (Ariesa, 2019). Sementara suatu kelompok masyarakat atau negara dikatakan telah mencapai kemandirian pangan apabila kelompok atau negara tersebut memiliki ciri: 1) meningkatnya produksi pangan domestik; 2) meningkatnya land-man ratio; 3) meningkatnya kemampuan pengelolaan cadangan pangan; 4) meningkatnya jangkauan jaringan distribusi dan pangan bagi produsen dan konsumen; dan 5) adanya kemampuan pemerintah dalam mengantisipasi dan tanggap dalam kerawanan pangan (Elizabeth, 2011).

Setelah memahami apa yang dimaksud dengan ketahanan pangan, maka bisa diteliti bagaimana tepatnya upaya masyarakat Sunda Kasepuhan Ciptagelar melalui pola bangunan mampu mencapai kedaulatan pangan. Masyarakat ini tinggal di Kampung Gede, Desa Sinar Resmi, Kecamatan Cisolok, Kabupaten Sukabumi. Berdasarkan lokasinya yang berada di kawasan Gunung Halimun kampung adat Kasepuhan Ciptagelar memiliki lingkungan geografis pegunungan dan perbukitan yang dipenuhi lembah dan sungai. Dikarenakan letaknya yang tinggi (600-900 m dpl), suhu disekitar cukup dingin, yaitu $20-30^{\circ}$ Celcius dengan curah hujan sekitar 5 bulan (Rahmawati dkk, 2008). 


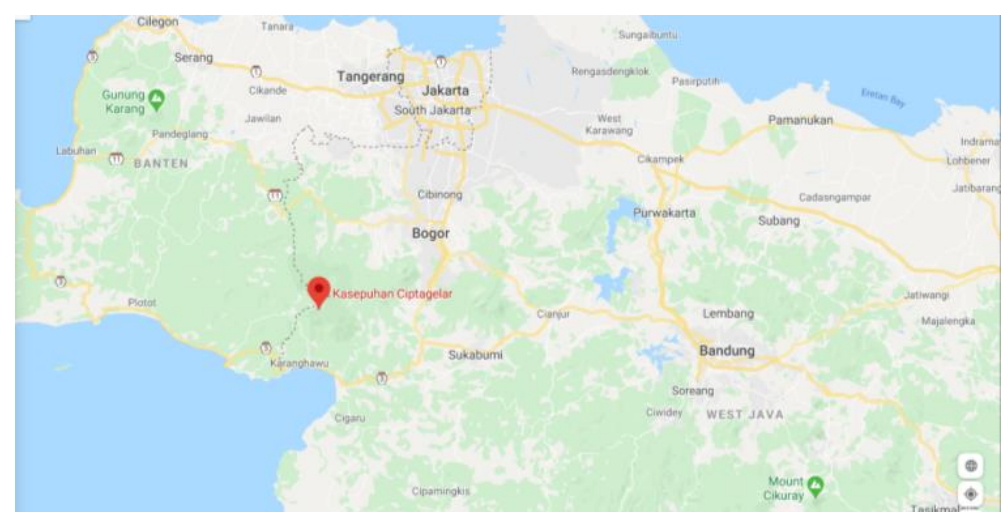

Gambar 1. Peta Jawa Barat dan lokasi Sunda Kasepuhan Ciptagelar Sumber: Google Map, 2019

Dalam penelitian ini, ketiga bangunan ini terbagi menjadi dua kepemilikan, yakni leuit, saung lisung, dan goah milik warga, termasuk milik Baris Kolot atau jajaran ahli adat; serta leuit rurukan, saung lisung rurukan, dan goah Imah Gede milik Sesepuh Girang (rurukan berarti milik adat). Baik leuit maupun leuit rurukan memiliki fungsi dan bentukan yang sama, hanya kepemilikannya yang berbeda. Berikut ini adalah penjelasan singkat mengenai ketiga bangunan obyek penelitian ini.

Dimulai dari leuit yaitu lumbung padi yang digunakan oleh masyarakat Sunda Kasepuhan, sebagai tempat menyimpan hasil panen. Leuit bisa juga disebut sebagai "bank padi" dikarenakan masyarakat ini menyimpan beras hasil panen dan menggunakan hasil panen dari tahun-tahun sebelumnya sehingga jumlah padi terus bertambah (Sumardjo, 2015). Tidak hanya sekedar sebagai tempat penyimpanan padi, leuit memiliki peran yang penting dalam budaya Sunda tradisional. Hal ini dikarenakan padi merupakan makanan pokok masyarakat ini dan leuit merupakan tumpuan agar tidak terjadinya kelaparan dalam kampung Sunda tersebut. Selain itu, dalam masyarakat Sunda tradisional, status kesejahteraan seseorang dapat dilihat dari berapa jumlah leuit yang dimilikinya. (Asep, 2000).

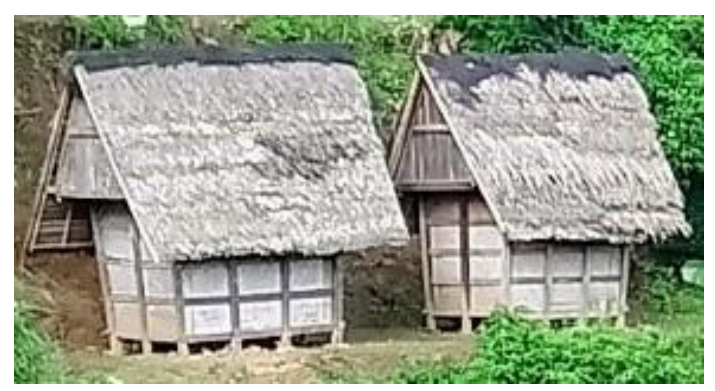

Gambar 2. Leuit

Sumber: Dokumentasi pribadi, 2020 
Saung lisung secara umum dapat dilihat sebagai sebuah bangunan sederhana yang hanya terdiri dari atap dan empat tiang penyangga dan berfungsi sebagai tempat pengolahan padi menjadi beras dengan cara ditumbuk. Bagi masyarakat Sunda tradisional, saung lisung merupakan salah satu bangunan yang penting dalam siklus padi. Jika tanpa leuit masyarakat Sunda tradisional tidak bisa menyimpan padi, maka tanpa saung lisung mereka tidak bisa mengolah padi menjadi beras. Di dalam saung lisung terdapat perkakas yang digunakan dalam menumbuk padi, yaitu alu dan lesung (Sumardjo, 2015).

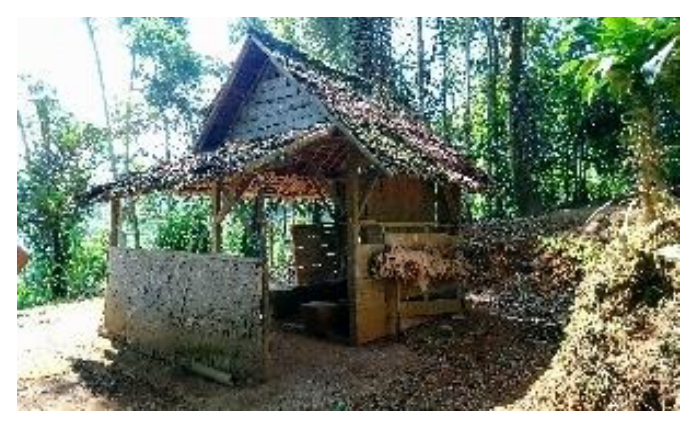

Gambar 3. Saung lisung

Sumber: Dokumen pribadi, 2020

Cara memasak beras menjadi nasi juga harus dilakukan sesuai tradisi dengan perkakas tradisi pula. Dalam masyarakat Sunda Kasepuhan Ciptagelar, memasak nasi hanya boleh dilakukan di goah atau area masak yang terletak di pawon atau dapur. Pawon sendiri terdiri dari beberapa area sesuai dengan fungsinya, yang pertama adalah area masak atau yang disebut goah, termasuk di dalamnya hawu atau tungku tempat memasak nasi; yang kedua adalah pangdaringan, sebuah bilik atau kamar berukuran kecil (1-1,5m panjang dan lebarnya) tempat meletakkan pabeasan atau gentong beras. Di dalam pangdaringan ini juga diletakkan berbagai sesaji, barang pusaka, dan beberapa alat pertanian. Hal ini dikarenakan masyarakat Sunda Kasepuhan percaya bahwa para leluhur ada di sana, menjaga dan mengawasi keluarga (Survei Lapangan, 2020). Dari penjelasan ini dapat dipahami bahwa goah bukanlah bangunan yang berdiri secara individu sebagaimana leuit dan saung lisung, melainkan merupakan bagian yang tidak terpisahkan dari rumah tinggal. 


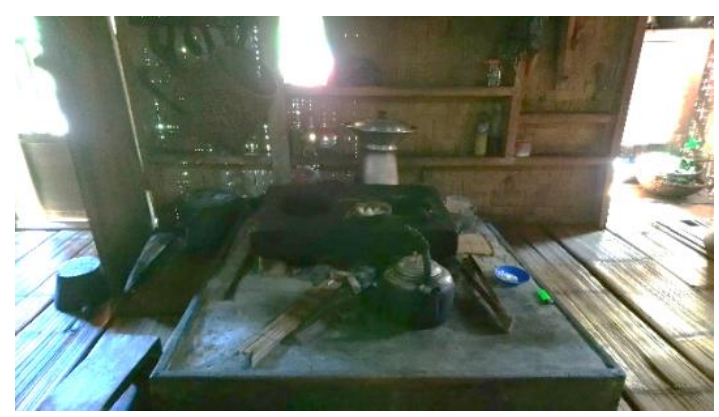

Gambar 4. Goah

Sumber: Dokumentasi pribadi, 2020

Setelah memahami penjelasan singkat atas masing-masing bangunan leuit, saung lisung, dan goah, maka penjelasan kembali dilanjutkan pada pola ketiga bangunan tersebut. Untuk itu dibuatlah ilustrasi site-plan dari Kampung Gede, yaitu kampung utama tempat tinggal masyarakat Sunda Kasepuhan Ciptagelar. Untuk mempermudah membaca makna dari jarak bangunan serta perannya dalam upaya yang dilakukan oleh masyarakat Sunda Ciptagelar dalam menjaga ketahanan pangan, peneliti membagi keterangan bangunan obyek penelitian di atas menjadi klaster-klaster kecil. Adapun cara pembagian klaster-klaster dalam site-plan tersebut adalah dengan mengelompokkan satu area hunian yang didasari oleh kepemilikan serta pemakaian bangunan tersebut (leuit, saung lisung, dan goah) terkait proses pengolahan pangan.

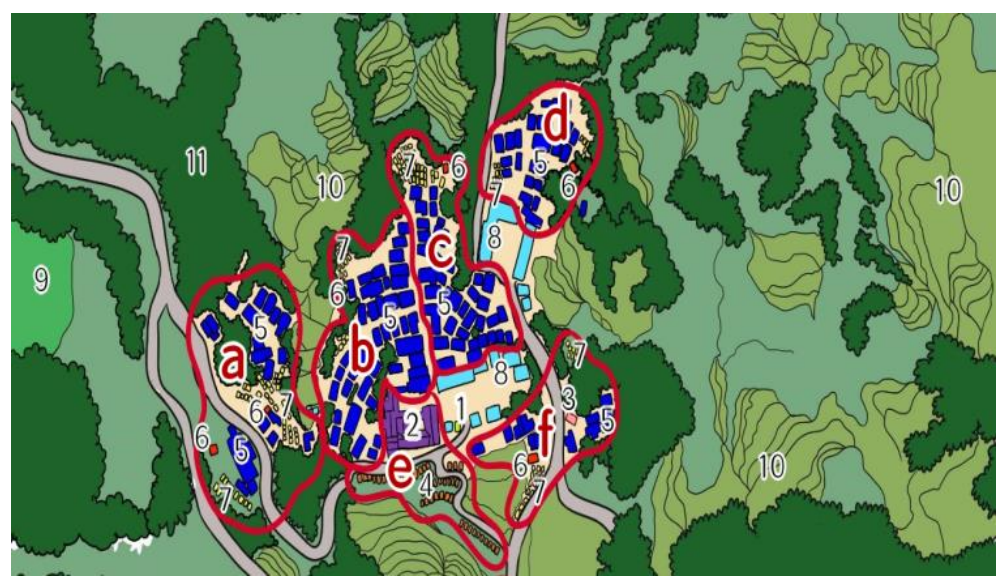

Gambar 5. Peta lokasi Kampung Gede, Sunda Kasepuhan Ciptagelar Sumber: Dimodifikasi dari Kusdiwanggo 2016, dan hasil observasi lapangan 2020 
Serat Rupa Journal of Design, January 2021, Vol.5, No.1: 55 - 79

E-ISSN: 2477-586X, ISSN: 2338-3348 | https://doi.org/10.28932/srjd.v5i1.2986 | Received: 25- 09- 2020, Accepted: 14 -01 - 2021

Afina Nisa Aulia, Gregorius Prasetyo Adhitama

Pola Bangunan Leuit, Saung Lisung, dan Goah pada Masyarakat Sunda Kasepuhan Ciptagelar

Keterangan gambar:

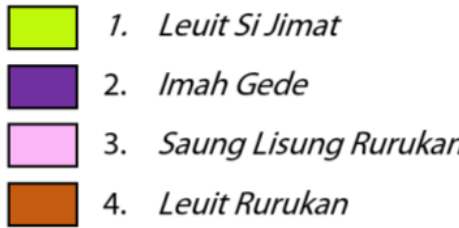

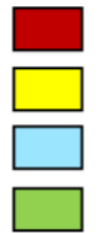

6. Saung Lisung

7. Leuit

8. Bangunan Publik

9. Huma
11. Hutan 


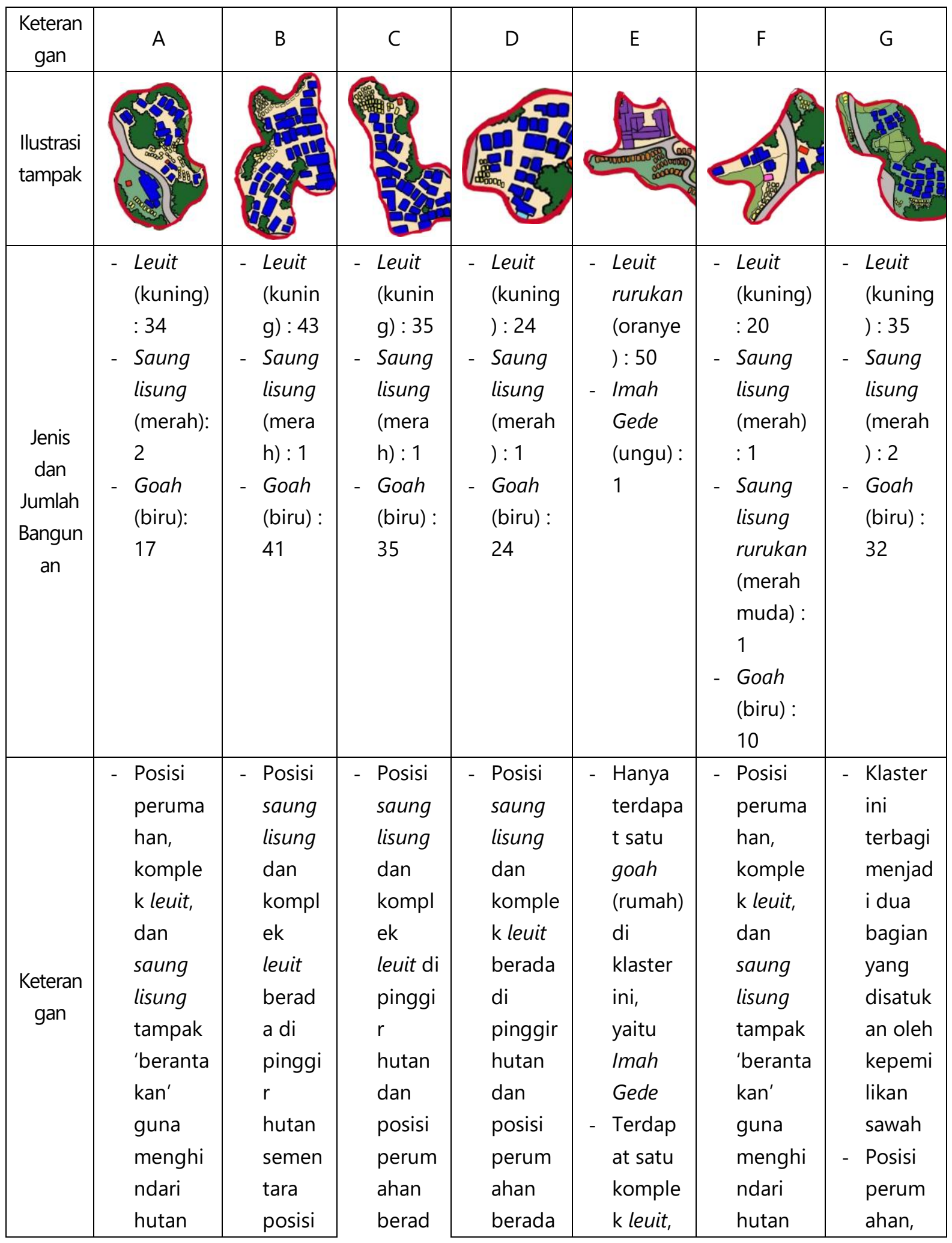




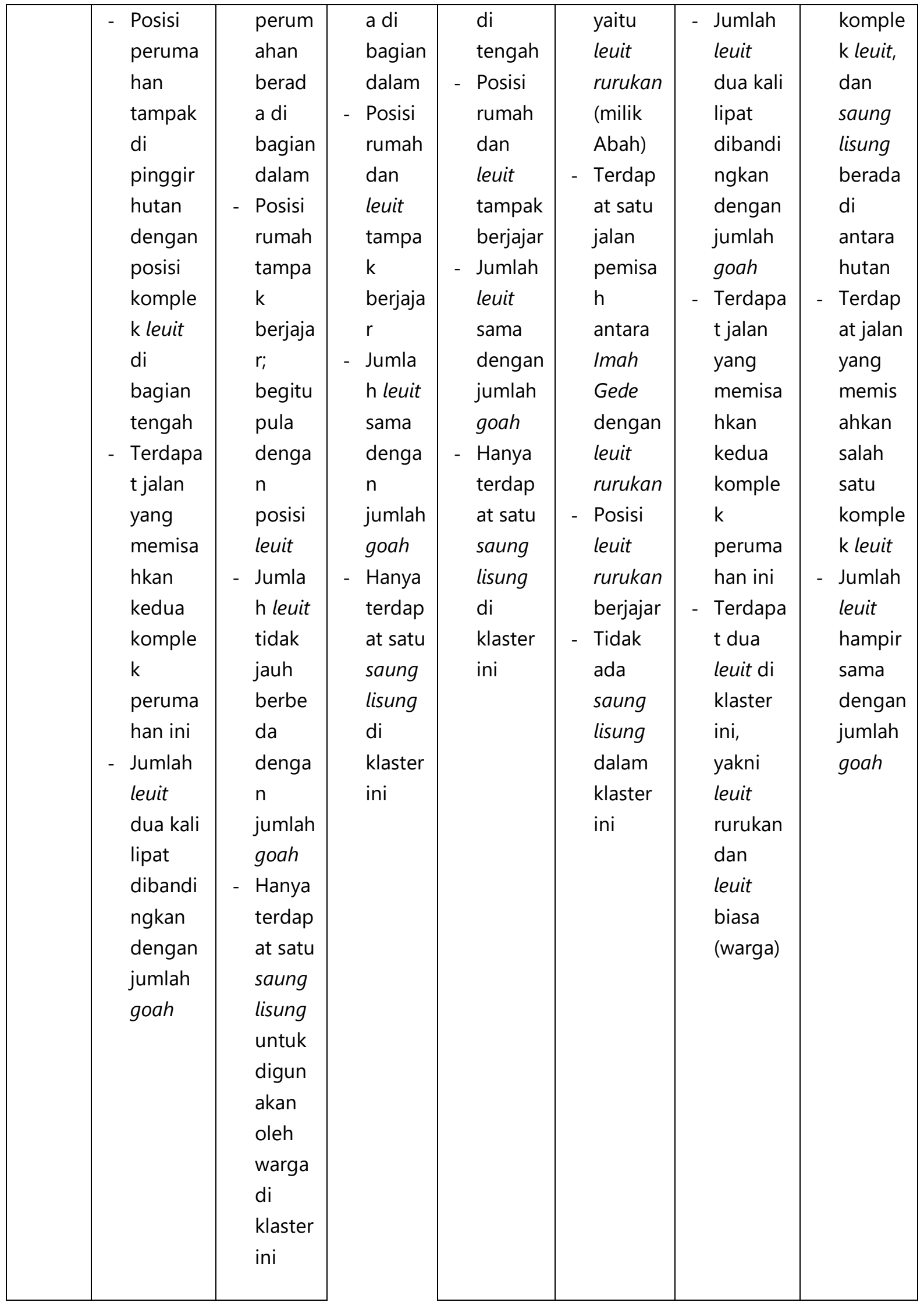


Terdapat beberapa kesimpulan yang bisa diambil dari tabel di atas, yakni:

1. Adanya pola bahwa dalam setiap klaster terdiri dari setidaknya satu komplek perumahan, satu komplek leuit, dan satu saung lisung.

Setiap klaster setidaknya terdiri dari satu komplek perumahan, satu komplek leuit, dan satu saung lisung. Hal ini dapat ditarik kesimpulan bahwa setiap klaster mampu bertanggung jawab atas kebutuhan pangannya masing-masing tanpa harus bergantung dengan klaster lain. Meski demikian, terdapat satu pengecualian, yaitu klaster E yang berisikan Imah Gede tidak memiliki saung lisung, sementara klaster F memiliki dua saung lisung (saung lisung warga dan saung lisung rurukan).

Untuk klaster E, goah yang ada dalam klaster ini adalah Imah Gede, yaitu bangunan tempat Sesepuh Girang tinggal. Bisa dikatakan, bagi masyarakat Sunda Kasepuhan Ciptagelar, Imah Gede adalah istana kerajaan di mana banyak kegiatan besar dilaksanakan, seperti upacara seren taun setiap tahunnya. Kegiatan ini dilaksanakan di lapangan dekat dengan Imah Gede dan balai desa dan dihadiri tidak hanya oleh seluruh warga Kasepuhan Ciptagelar, tetapi juga berbagai tamu luar Kampung Gede itu sendiri. Dikarenakan kebutuhan tersebut, para perempuan di Imah Gede, dibawah pengawasan Emak (istri Sesepuh Girang), menumbuk padi dalam jumlah yang sangat besar sekaligus dan mampu bertahan hingga hitungan bulan. Berdasarkan beberapa alasan inilah saung lisung rurukan tidak dibangun dekat dengan Imah Gede. Adapun alasan klaster $\mathrm{F}$ memiliki dua saung lisung, dikarenakan saung lisung rurukan berukuran besar dengan peralatan yang cukup lengkap untuk digunakan, banyak warga di sekitar saung datang dan menumbuk di sana meskipun bukan untuk kepentingan Imah Gede. Frekuensi pemakaian saung lisung rurukan oleh warga jauh lebih banyak dibandingkan dengan pemakaian saung lisung oleh penghuni Imah Gede sehingga saung lisung rurukan masuk ke dalam kategori klaster $\mathrm{F}$.

\section{Posisi komplek rumah atau goah, leuit, dan saung lisung menghindari hutan.}

Tampak komplek rumah, komplek leuit, dan saung lisung dengan sengaja menghindari hutan. Bahkan dalam beberapa kasus (klaster F), komplek leuit tampak terpisah dari komplek perumahan agar menghindari hutan. Hal ini disebabkan oleh kepercayaan masyarakat Sunda Kasepuhan bahwa arwah leluhur atau karuhun menempati wilayah hutan, terutama jenis hutan yang lebat dan rapat leuweung tutupan. Hal inilah yang menyebabkan posisi rumah, leuit, dan saung lisung diatur sedemikian rupa untuk menghindari menebang pohon dari hutan-hutan tersebut dan dengannya terbentuklah klaster-klaster ini. 


\section{Jumlah goah (rumah) dan leuit sekurang-kurangnya 1:1 tiap klaster}

Berdasarkan hasil wawancara yang dilakukan pada beberapa warga Kasepuhan, setiap keluarga dalam satu rumah memiliki setidaknya satu leuit untuk kebutuhan pangan

mereka. Jika pada panen selanjutnya jumlah padi melebihi kapasitas leuit, maka leuit kedua akan dibangun, dan demikian seterusnya. Hal ini dibuktikan dari ilustrasi site-plan yang menunjukkan jumlah leuit yang sama, beberapa klaster bahkan memiliki jumlah leuit lebih banyak dibandingkan dengan rumah tinggal.

\section{Jumlah saung lisung hanya satu (dua, paling banyak) dalam tiap klaster}

Berbeda dengan leuit, tidak setiap rumah tangga memiliki satu alat untuk menumbuk padi. Dalam satu klaster hanya terdapat satu atau paling banyak dua saung lisung, di mana sasung lisung merupakan bangunan komunal digunakan bersama-sama. Dikarenakan banyaknya pengguna, biasanya para kaum perempuan yang bertugas akan menumbuk beras dalam jumlah yang diperkirakan cukup untuk seminggu atau bahkan dua minggu. Berdasarkan perhitungan ini, ditambah dengan adanya pamali yang melarang mereka untuk sebisa mungkin tidak menumbuk di hari kelahiran suami dan istri dalam satu rumah tangga, pemakaian saung lisung ini dapat dimaksimalkan dan tidak adanya dorongan untuk membangun saung lisung dalam jumlah banyak.

\section{Leuit milik perorangan namun tetap berkumpul dalam satu komplek}

Sesuai hasil wawancara dengan warga, dapat dipahami bahwa leuit yang merupakan lumbung tempat penyimpanan padi merupakan milik perorangan atau per keluarga. Masing-masing keluarga minimal memiliki satu leuit atau bahkan lebih untuk kebutuhan pangan sehari-hari. Meski demikian, seperti yang terlihat dalam ilustrasi site-plan di atas, leuit tidak dibangun di belakang rumah, misalnya, melainkan dikumpulkan menjadi satu komplek mesi tetap dekat dengan komplek perumahan. Adapun alasan leuit ini disatukan menjadi satu komplek dikarenakan dengan demikian leuit mudah untuk diawasi bersama dan mempermudah pemeliharaan secara bergotong-royong.

Dari ilustrasi site-plan sebelumnya, dibuat rangkuman data tersebut dalam bentuk matriks agar lebih mudah dipahami. 


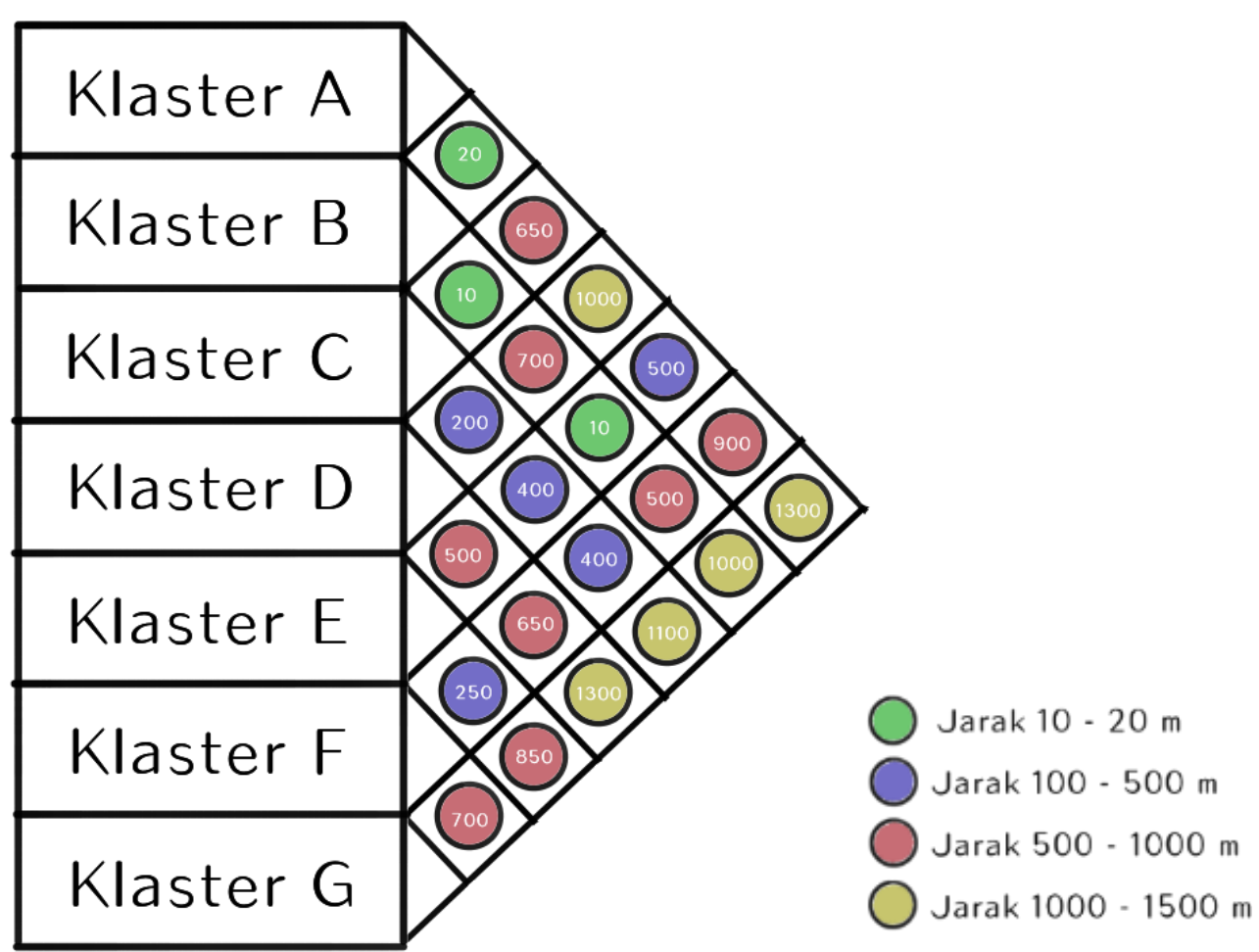

Gambar 6. Matriks jarak antar klaster Sumber: Dokumen pribadi 2020

Berikut ini adalah keterangan jarak secara fenomena (tak terukur).

Tabel 2. Keterangan matriks

\begin{tabular}{|c|c|}
\hline Klaster & Fenomena \\
\hline$A-B$ & $\begin{array}{l}\text { - Kedua klaster ini dipisahkan dengan sawah dan hutan kecil } \\
\text { - Untuk berkunjung dapat menggunakan "jalan utama" berupa jalanan tanah yang } \\
\text { sudah diratakan atau menggunakan jalan pintas, yaitu melalui sawah dan jalan } \\
\text { setapak kecil }\end{array}$ \\
\hline$A-C$ & $\begin{array}{l}\text { - Klaster C sangat berdekatan dengan wilayah Imah Gede } \\
\text { - Untuk berjalan ke klaster A dari klaster C, pejalan kaki bisa menggunakan jalan utama } \\
\text { atau menggunakan jalan pintas }\end{array}$ \\
\hline$A-D$ & $\begin{array}{l}\text { - Biasanya masyarakat yang datang dari klaster A ke klaster D menggunakan kendaraan } \\
\text { motor sehingga jalan yang paling sering digunakan adalah jalan utama. } \\
\text { - Jalanan berubah menjadi jalan berbatu dan agak menurun ke bawah, melewati } \\
\text { bangunan sekolah, dan barulah sampai di perumahan dan komplek leuit serta saung } \\
\text { lisung } \\
\text { - Tidak terlalu banyak pohon selama perjalanan sehingga perumahan klaster D dapat } \\
\text { terlihat dengan jelas dari jalan utama }\end{array}$ \\
\hline
\end{tabular}




\begin{tabular}{|c|c|}
\hline$A-E$ & $\begin{array}{l}\text { - Klaster E merupakan klaster tempat Imah Gede berada, sehingga warga klaster A akan } \\
\text { datang untuk berbagai keperluan (menghadap Sesepuh Girang dan perayaan seren } \\
\text { taun) } \\
\text { - Jalan tercepat dan termudah adalah dengan menggunakan jalan utama yang luas dan } \\
\text { rata, meski tidak terlindung oleh pepohonan yang rindang }\end{array}$ \\
\hline$A-F$ & $\begin{array}{l}\text { - Jalan paling cepat dengan menggunakan jalan utama yang cukup luas dan kering } \\
\text { - Jalan ini tidak memiliki tempat yang teduh karena pepohonan di sekitar jalan } \\
\text { dipangkas }\end{array}$ \\
\hline$A-G$ & $\begin{array}{l}\text { jarang warga dari kedua klaster ini yang saling berkunjung } \\
\text { paling mudah adalah melalui jalan utama }\end{array}$ \\
\hline$B-C$ & $\begin{array}{l}\text { - Kedua klaster ini merupakan kelompok perumahan Sesepuh Girang, Baris Kolot } \\
\text { - Kedua klaster ini memiliki lingkungan dan suasana: luas, padat akan perumahan, dan } \\
\text { tidak terlalu banyak pohon besar dan lebat } \\
\text { - Kedua klaster dipisahkan oleh satu jalan lebar yang merupakan cabang dari jalan } \\
\text { utama. }\end{array}$ \\
\hline$B-D$ & $\begin{array}{l}\text { laster B ke klaster D adalah untuk ke sekolah } \\
\text { an melintasi lapangan dan turun ke klaster D } \\
\text { k dihalangi oleh pepohonan, semak belukar atau sawah }\end{array}$ \\
\hline$B-E$ & $\begin{array}{l}\text { - Denga } \\
\text { B) ini s }\end{array}$ \\
\hline$B-F$ & B bisa ke klaster $C$ \\
\hline$B-G$ & - Warg \\
\hline$C-D$ & $\begin{array}{l}\text { Dh } \\
\text { D } \\
\text { ar atau sawah }\end{array}$ \\
\hline$C-E$ & $\begin{array}{l}\text { - Denga } \\
\text { C) ini } 5\end{array}$ \\
\hline $\mathrm{C}-\mathrm{F}$ & - Deng \\
\hline$C-G$ & bih sering melewati jalan utama menggunakan kendaraan \\
\hline$D-E$ & $\begin{array}{l}\text { ki sedikit dan langsung keluar di lapangan dekat } \\
\text { ter E) }\end{array}$ \\
\hline$D-F$ & - Warga klaster D harus sedikit mendaki di jalanan berbatu untuk sampai ke klaster E. \\
\hline$D-G$ & $\begin{array}{l}\text { - Perjalanan dari klaster D ke klaster G dimana warga dari klaster D harus berjalan cukup } \\
\text { jauh sebelum mendaki sedikit, melewati klaster } F \text {, masih jalan terus menggunakan } \\
\text { jalan utama dan barulah akhirnya sampai di klaster } G\end{array}$ \\
\hline$E-F$ & $\begin{array}{l}\text { - Cara para warga dari klaster E ke klaster F sangatlah mudah, hanya terpisahkan oleh } \\
\text { satu lapangan besar }\end{array}$ \\
\hline$E-G$ & $\begin{array}{l}\text { - Warga klaster G tinggal mengikuti jalan utama dengan pemandangan sawah di } \\
\text { bagian kanan-kiri jalan dan jajaran leuit rurukan, sudah sampai ke Imah Gede (klaster } \\
\text { E) }\end{array}$ \\
\hline$F-C$ & $\begin{array}{l}\text { - Warga klaster } F \text { mengikuti jalan dengan pemandangan sawah dan hutan di kanan } \\
\text { jalan ke klaster } G\end{array}$ \\
\hline
\end{tabular}


Berdasarkan pengamatan di atas, maka dapat diambil beberapa kesimpulan terkait jarak secara fenomena (tak terukur) antar klaster di Kampung Gede Sunda Kasepuhan Ciptagelar ini, diantaranya:

1. Adanya satu jalan utama yang menghubungkan seluruh klaster ini menjadi satu.

2. Tidak adanya pola yang sama terkait jarak matematis antar masing-masing klaster, contoh:

a. Klaster $\mathrm{G}$ merupakan klaster terjauh dari klaster lainnya, dengan jarak paling jauh 1,3 km dan paling dekat $700 \mathrm{~m}$.

b. Klaster $\mathrm{D}$ paling sering dikunjungi karena disitulah letak sekolah (tidak berkaitan dengan proses pengolahan padi dan beras)

c. Klaster E paling sering dikunjungi untuk menghadap Sesepuh Girang

d. Klaster $\mathrm{F}$ mengalami puncak pengunjung pada saat acara seren taun dan nganyaran

Kesimpulan di atas menyiratkan bahwa sesungguhnya masing-masing warga dalam tiap klaster tidak mengunjungi klaster yang laing kecuali ada urusan penting. Selain jarak yang cukup jauh, banyak jalan yang tidak terlalu memadai untuk dipakai jalan dari satu klaster ke klaster lainnya kecuali menggunakan jalan utama yang secara matematis lebih jauh dari jalan pintas. Meski demikian, tidak ada satu klaster pun yang kesulitan dalam memenuhi kebutuhan pangan harian. Hal ini menunjukkan bahwa kedaulatan pangan ini bersifat menyeluruh di setiap klaster.

Jarak antara leuit, saung lisung, dan goah dalam tiap klaster kurang lebih sama. Untuk mempermudah dalam membaca data jarak antar bangunan, data dibagi menjadi tiga kelompok, yakni bangunan properti warga, bangunan properti Baris Kolot dan bangunan properti Sesepuh Girang. Properti milik warga dan Baris Kolot memiliki nama yang sama, yakni leuit, saung lisung, dan goah hanya dibedakan nama kepemilikan di belakangnya; sementara properti milik Sesepuh Girang ditambahkan kata rurukan (milik adat). 


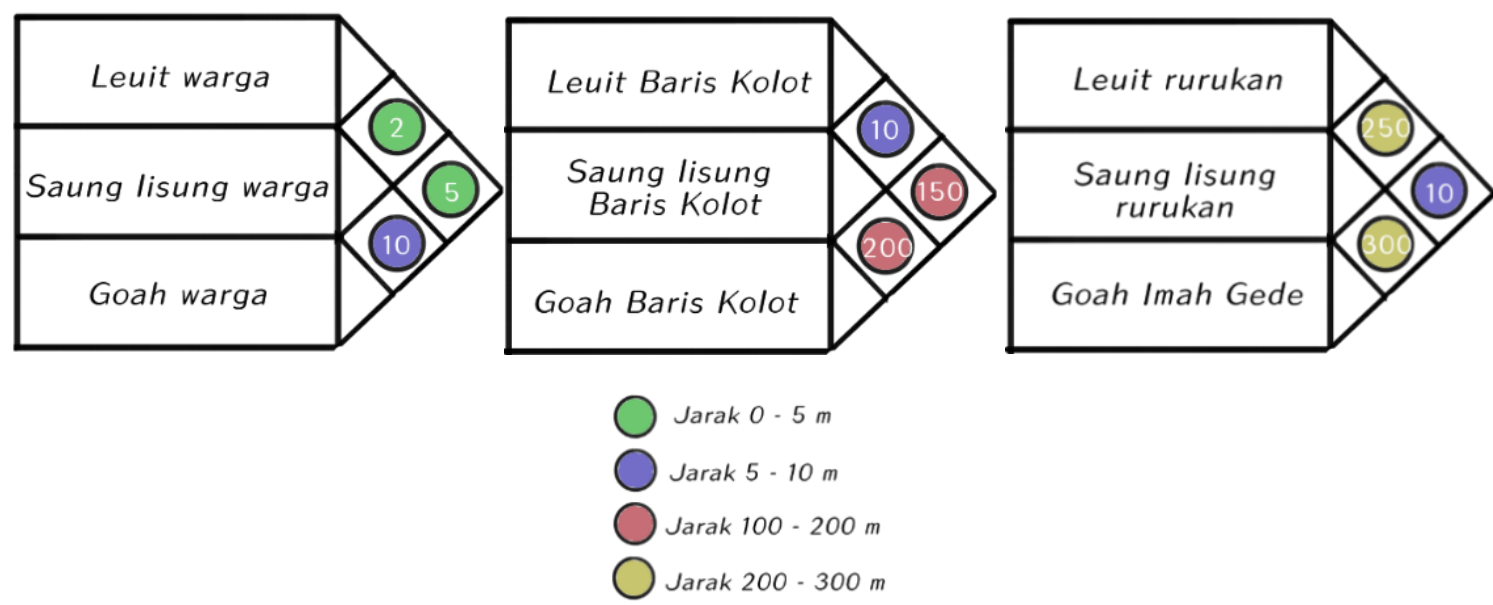

Gambar 7. Matriks jarak antar bangunan dalam klaster Sumber: Dokumen pribadi, 2020

\section{Jarak antar leuit, saung lisung, dan goah milik warga}

Berdasarkan data matriks yang disediakan di atas, dapat dilihat jarak tiap bangunan dalam satu klaster sangat kecil: leuit - saung lisung 5 m; saung lisung - goah 10 m; dan leuit - goah $5 \mathrm{~m}$.

\section{Jarak antar leuit, suang lisung, dan goah milik Baris Kolot}

Baris Kolot harus selalu berada di dekat Abah, karenanya rumah tiap Baris Kolot berada dekat dengan Imah Gede. Inilah mengapa jarak antara rumah dengan bangunan lainnya menjadi jauh: leuit - saung lisung 10m; saung lisung - goah 200m; dan leuit - goah 200m.

\section{Jarak antar leuit rurukan, saung lisung rurukan, dan Imah Gede milik Sesepuh Girang}

Perbedaan jarak bangunan properti Sesepuh Girang tampak drastis. Imah Gede adalah istana kerajaan di mana banyak kegiatan besar dilaksanakan, seperti upacara seren taun (syukuran atas keberhasilan panen) dan upacara nganyaran (kegiatan menumbuk padi pertama hasil panen) setiap tahunnya. Dikarenakan kebutuhan tersebut, para perempuan di Imah Gede, dibawah pengawasan Emak (istri Sesepuh Girang), menumbuk padi dalam jumlah yang sangat besar sekaligus dan mampu bertahan hingga hitungan bulan. Berdasarkan beberapa alasan inilah saung lisung rurukan tidak dibangun dekat dengan Imah Gede.

Data di atas menyatakan bahwa jarak bangunan antar klaster lebih kepada posisi yang strategis: leuit dekat dengan sawah, saung lisung dekat dengan leuit, dan goah dekat dengan leuit dan goah. Akan tetapi aturan ini tidak berlaku jika ada alasan penting yang menyebabkannya, sebagai contoh Imah Gede perlu berada dekat dengan lapangan untuk berbagai acara dan keperluan sehingga tidak bisa memiliki saung lisung dalam jarak dekat; dan jajaran Baris Kolot harus berada dekat 
Serat Rupa Journal of Design, January 2021, Vol.5, No.1: 55 - 79

E-ISSN: 2477-586X, ISSN: 2338-3348 | https://doi.org/10.28932/srjd.v5i1.2986 | Received: 25- 09- 2020, Accepted: 14 -01 - 2021 Afina Nisa Aulia, Gregorius Prasetyo Adhitama

dengan Imah Gede sehingga tidak memungkinkan untuk berada dalam jarak dekat dengan saung lisung dan leuit. 
Dalam data lingkungan site-plan, keterangan dibagi menjadi skema per area sesuai kebutuhan, yakni data seluruh jarak Imah Gede, saung lisung rurukan, leuit rurukan, goah, saung lisung, dan leuit.

\begin{tabular}{|c|c|}
\hline $\begin{array}{l}\text { Skema Jarak Saat Proses Pengolahan } \\
\text { Padi dan Beras Sesepuh Girang } \\
\qquad 300 \mathrm{~m}\end{array}$ & Jarak terjauh (milik Baris Kolot) \\
\hline $\begin{array}{l}\text { Keterangan } \\
\text { Dilihat dari skema di atas, dapat } \\
\text { disimpulkan bahwa jarak saung } \\
\text { lisung rurukan cukup jauh dari imah } \\
\text { gede dan komplek leuit rurukan. Hal } \\
\text { ini dikarenakan peletakan saung } \\
\text { lisung diatur agar berada di area } \\
\text { yang cukup luas pada saat perayaan } \\
\text { Seren Taun dan melaksakan ritual } \\
\text { Nganyaran. Letak saung lisung } \\
\text { rurukan yang cukup jauh ini tidak }\end{array}$ & $\begin{array}{l}\text { Keterangan } \\
\text { Berdasarkan diagram di atas, dapat dilihat bahwa } \\
\text { jarak antara tiga kegiatan } \\
\text { (menyimpan/mengambil padi, menumbuk padi, } \\
\text { dan memasak beras) sangat berdekatan satu } \\
\text { sama lain. Jarak terjauh pun hanya berjarak } 200 \\
\text { meter, dan disebabkan oleh komplek perumahan } \\
\text { besar (dekat dengan Imah Gede). Meski demikian } \\
\text { jarak ini tidak menjadi penghalang bagi warga } \\
\text { dalam melakukan berbagai aktifitas terkait }\end{array}$ \\
\hline
\end{tabular}


Mahimma Romadhona, Aileena Solicitor Costa Rica El Chidtian, Roziana Febrianita

Kajian Bela Negara Pada Desain Kostum dan Atribut Superhero Panca Satria

\begin{tabular}{|l|l|}
\hline mengganggu kegiatan makan & pangan seperti mengambil dan menumbuk padi \\
keseharian, mengingat penghuni & tiap 1 atau 2 minggu sekali. \\
Imah Gede menumbuk padi dalam & \\
jumlah besar hingga tahan untuk & \\
beberapa minggu bahkan hitungan \\
bulan sehingga proses menumbuk \\
tidak perlu dilakukan dalam waktu \\
yang berdekatan.
\end{tabular}

Skema Perbandingan Jarak Proses Pengolahan Padi dan Beras Warga dan Sesepuh Girang


Skema ini menampilkan jarak terdekat antar Imah Gede - goah; leuit rurukan - leuit; dan saung lisung rurukan - saung lisung, untuk memperlihatkan jarak antara properti warga dengan properti Sesepuh Girang.

B. Jarak terjauh

Skema ini menampilkan jarak terjauh antar Imah Gede - goah; leuit rurukan - leuit; dan saung lisung rurukan - saung lisung, untuk memperlihatkan jarak antara properti warga dengan properti Sesepuh Girang.

C. Jarak terdekat

Skema ini menampilkan jarak terdekat antar Imah Gede - leuit; Imah Gede - saung lisung; dan goah - leuit rurukan, untuk memperlihatkan jarak antara properti warga dengan properti Sesepuh Girang.

D. Jarak terjauh

Skema ini menampilkan jarak terdekat antar Imah Gede - leuit; Imah Gede - saung lisung; dan goah - leuit rurukan, untuk memperlihatkan jarak antara properti warga dengan properti Sesepuh Girang.

Jika disimpulkan, skema di atas jelas menunjukkan adanya perbedaan jarak yang signifikan antara ketiga bangunan proses pengolahan padi (leuit, saung lisung, dan goah) milik warga dengan milik Sesepuh Girang. Perbedaan jarak ini menunjukkan bahwa adanya kemandirian tiap keluarga termasuk penghuni Imah Gede dalam mengelola pangan, terutama nasi, dalam kesehariannya. Hasilnya, jarak antar komplek goah atau antar leuit atau antar saung lisung bisa saja saling berjauhan asalkan dalam satu klaster masing-masing harus terdiri atas leuit, saung lisung, dan goah.

Berdasarkan hasil analisis di atas maka dapat diambil beberapa temuan penelitian (findings) terkait hubungan pola bangunan leuit, saung lisung, dan goah dalam budaya bertani masyarakat Sunda Kasepuhan Ciptagelar sebagai upaya menjaga ketahanan pangan. 
1) Setiap satu kelompok warga Kasepuhan Ciptagelar dalam satu klaster memiliki masing-masing kelompok leuit, satu saung lisung, dan goah pribadi dalam jarak yang dapat dijangkau (dekat) dan mudah untuk dijangkau (medan tidak sulit). Secara teoris, hal ini memiliki arti bahwa ketiga bangunan ini memegang peran yang sangat penting dan signifikan bagi masyarakat Sunda Kasepuhan Ciptagelar, yaitu sebagai suatu institusi sosial yang memiliki nilai integratif. Dalam hal ketahanan pangan, fakta ini menjadikan tercapainya kemandirian pangan dimana setiap kelompok warga dalam satu klaster tidak perlu bergantung dengan klaster lain untuk memenuhi kebutuhan pangan.

2) Letak dan posisi bangunan leuit, saung lisung, dan goah di setiap klaster dilaporkan dan diketahui dengan baik oleh pemerintahan adat, atau Sesepuh Girang. Artinya pemerintah adat memiliki informasi terkait letak tiap klaster, jumlah leuit (hasil panen tiap warga), jumlah saung lisung, dan goah (rumah tinggal). Hal ini menjadikan pemerintah adat mampu bertindak cepat jika satu atau lebih klaster memerlukan bantuan dari sisi pangan.

\section{B. Hasil dan Pembahasan}

Adapun tahapan yang dilakukan untuk ditemukannya hasil penelitian ini dimulai dari penggunaan teori yang didukung oleh elemen budaya masyarakat Kasepuhan Ciptagelar. Teori yang digunakan adalah teori Ruang dan Jarak yang digagas oleh Edward Relph. Di dalam teori ini dinyatakan bahwa jarak antar bangunan atau letak dan posisi suatu bangunan dalam budaya menentukan identitas (tingkat pentingnya) bangunan tersebut dalam masyarakat/etnis tersebut (Seamon dan Sowers, 2008). Selain itu, Criparacos dalam tesisnya juga menyebutkan bahwa jarak dalam arsitektur adanya pergerakan (dinamis) yang artinya jarak ini diatur sesuai dengan kebutuhan, karena ia bersifat dinamis (Criparacos, 1987). Artinya jarak ini tidak memiliki aturan yang pakem untuk diam dalam satu titik yang sama, itulah mengapa posisi leuit, saung lisung, dan goah masing-masing jaraknya bisa berbeda-beda, disesuaikan dengan data yang di dapat dari matriks di atas, tergantung kepemilikan dan kebutuhan masing-masing bangunan tersebut. Pemahaman ini kemudian dilihat lebih jauh dengan menggunakan sudut pandang elemen budaya masyarakat Sunda Kasepuhan, yakni tilu sapamilu atau tritangtu, tatali paranti karuhun, dan peran ketua adat atau pemerintahan adat, yakni Sesepuh Girang dan Baris Kolot. Untuk memahami bagaimana tepatnya ketiga elemen 
Mahimma Romadhona, Aileena Solicitor Costa Rica El Chidtian, Roziana Febrianita Kajian Bela Negara Pada Desain Kostum dan Atribut Superhero Panca Satria

ini berperan dalam menganalisis jarak di penelitian ini, perlu dipahami pengertian dari masing-masing elemen tersebut, yakni:

\section{a. Tilu sapamilu (Falsafah hidup)}

Secara singkat dapat dipahami bahwa masyarakat Sunda Kasepuhan memiliki pandangan hidup bahwa segala sesuatunya harus seimbang. Diawali dengan konsep dualisme, yang memahami bahwa dunia memiliki dua entitas (wujud) yang saling berlawanan, konsep tilu sapamilu ini berarti menggabungkan dua entitas yang saling bertolakbelakang tersebut menjadi satu kesatuan. Dengan demikian, tilu sapamilu ini berperan sebagai pemersatu dan menghasilkan entitas ketiga yang merupakan hasil gabungan dan atau penghubung dari dua entitas sebelumnya, dan dengannya memunculkan suatu sistem hubungan bersifat dinamika non-linear. Dalam penelitian ini, dapat dilihat bahwa ketiga entitas ini diwakili oleh leuit, saung lisung, dan goah dimana ketiga bangunan ini merepresentasikan keseimbangan dalam hal proses pengolahan padi dan beras. Sehingga dapat dipahami bahwa ketiga bangunan ini harus selalu ada di dalam tiap klaster agar proses pengolahan padi dan beras menjadi seimbang dan harmonis.

\section{b. Tatali paranti karuhun (Kepercayaan adat)}

Arti dari tatali paranti karuhun kurang lebih adalah mematuhi cara menjalani kehidupan sebagaimana yang dilakukan oleh para leluhur (karuhun). Tatali paranti karuhun itu sendiri berasal dari kata tali dalam bahasa Sunda, dimana bagi masyarakat Sunda, tali tersebut digunakan sebagai pengikat dan pengukur sehingga secara simbolis melambangkan suatu keterikatan dan ukuran dalam menjalani kehidupan hingga kembali ke asal. Hal ini menyebabkan tatali paranti karuhun sebagai sesuatu yang sakral dan harus ditaati sehingga siapapun yang tidak mengikutinya dianggap celaka (kabendon) dan akan membawa malapetaka tidak hanya bagi dirinya sendiri, tetapi juga bagi seluruh warga masyarakat Kasepuhan. Salah satu cara yang digunakan oleh karuhun diantaranya adalah penggunaan leuit, saung lisung, dan goah dalam mengolah padi dan beras. Hal ini pula yang menjadikan ketiga bangunan ini tidak bisa dipisahkan dan atau digantikan dengan teknologi modern. Selain itu, dalam perspektif jarak, sistem kepercayaan ini yang mengatur bagaimana posisi tiap area, termasuk bangunan dan tiap kluster boleh didirikan. Diantara aturan nenek moyang ini adalah larangan membuka lahan di area leuweung geledegan (hutan terlarang) dan hanya 
boleh di area leuweung sampalan, setelah lokasi tersebut disetujui untuk dibuka oleh Ketua Adat.

\section{c. Pemerintahan adat}

Sebagai kelompok masyarakat adat, masyarakat Sunda Kasepuhan dipimpin oleh ketua adat yang bagi masyarakat ini disebut sebagai Sesepuh Girang dan memiliki gelar Abah. Seluruh masyarakat Kasepuhan, tanpa pengecualian, patuh dan percaya sepenuhnya terhadap anjuran dan larangan yang diperintahkan oleh Sesepuh Girang. Hal ini dikarenakan masyarakat Kasepuhan percaya bahwa tidak sembarang orang bisa menjadi Sesepuh Girang, yakni hanya orang yang terpilih lah dan yang mendapatkan titisan daya spiritual dari para leluhur atau karuhun yang bisa melanjutkan kepemimpinan di kelompok masyarakat Kasepuhan. Salah satu tugas dari Sesepuh Girang adalah memastikan bahwa seluruh kegiatan terkait proses pengolahan padi dan beras yang berlangsung di Kasepuhan Ciptagelar dilangsungkan sesuai dengan ajaran nenek moyang terdahulu: ritual adat, waktu pelaksanaan, lokasi, pengguna, fasilitas, dan lain sebagainya.

Tidak hanya itu saja, sebagaimana yang telah dijelaskan dalam subbab tatali paranti di atas, adanya aturan bahwa diizinkan membuka setelah lokasi tersebut disetujui untuk dibuka oleh Sesepuh Girang dan Baris Kolot. Izin membuka lahan ini juga memiliki arti bahwa petani tidak tinggal jauh dari lahan penanaman padi, dan disanalah dibangun rumah (tentu termasuk goah). Dan jika ada goah, maka tentu tak jauh dari sana dibangun leuit dan saung lisung. Tidak hanya itu saja, dengan adanya aturan bahwa membuka lahan baru boleh dilakukan setelah mendapat ijin dari Sesepuh Girang, maka tidak ada satupun klaster yang lokasinya tidak diketahui oleh pemerintahan adat ini. Hal ini memudahkan pemerintahan adat untuk mengetahui lokasi warga Kasepuhan Ciptagelar sekiranya ada yang membutuhkan bantuan, terutama berupa bahan pangan.

Selanjutnya akan dibahas arti posisi dan jarak leuit, saung lisung, dan goah di setiap klaster berdasarkan teori dan ketiga elemen budaya tersebut. Berdasarkan teori Ruang dan Jarak Relph, jarak tiap bangunan menunjukkan tingkat kepentingan bangunan tersebut bagi satu kelompok masyarakat, dan dengannya dapat dipahami identitas dari bangunan itu sendiri. Adanya ketiga bangunan di setiap klaster menunjukkan betapa pentingnya penggunaan leuit, saung lisung, dan goah, menjadikan ketiga bangunan tersebut tak terpisahkan atau 
memiliki nilai integratif, yang jika satu hilang akan merusak seluruh sistem yang ada. Ketiga bangunan ini juga menjadi satu identitas yang khas dari masyarakat Sunda Kasepuhan Ciptagelar dalam mengolah padi dan beras. Sementara menurut teori Jarak dalam Arsitektur yang dikaji oleh Criparacos, jarak bersifat dinamis dan disesuaikan dengan kebutuhan pengguna tiap-tiap bangunan tersebut. Dilihat dari fakta bahwa ketiga jenis bangunan, yakni leuit, saung lisung, dan goah memiliki jarak yang berdekatan menunjukkan adanya urgensi atau kebutuhan dari pengaturan tersebut.

Adapun dasar dan kebutuhan mengapa diperlukannya ketiga jenis bangunan obyek penelitian ini dengan jarak yang saling berdekatan dipengaruhi oleh elemen budaya masyarakat Sunda Kasepuhan Ciptagelar itu sendiri, yakni: 1) tilu sapamilu, dimana kehidupan harus seimbang dan dengannya diperlukan masing-masing leuit (tempat menyimpan padi), dan goah (tempat memasak beras) yang merepresentasikan dua entitas dengan saung lisung (proses perubahan padi menjadi beras) sebagai entitas ketiga yang menghubungkan kedua entitas tersebut; 2) tatali paranti karuhun, yaitu agar memiliki hidup yang baik, perlu mengikuti bagaimana cara nenek moyang/leluhur dalam menjalani hidup, diantaranya adalah segala tahapan pengolahan padi dan beras menggunakan fasilitas leuit, saung lisung, dan goah ; dan 3) pemerintahan adat, yang dipimpin oleh Sesepuh Girang, dimana menurut kepercayaan mereka merupakan orang yang memiliki kemampuan sebagai jembatan antara warga dengan para leluhur atau karuhun. Segala bentuk perintah dari Sesepuh Girang ini harus ditaati, diantaranya adalah kewajiban menaati aturan nenek moyang dan penentuan lokasi dibangunnya kelompok perumahan, leuit, dan saung lisung.

C. Kesimpulan

Dari pembahasan di atas, maka dapat ditarik hasil penelitian bahwasanya jarak tiap-tiap bangunan leuit, saung lisung, dan goah yang membentuk satu pola memiliki hubungan langsung dengan kedaulatan pangan yang telah dicapai oleh masyarakat Sunda Kasepuhan Ciptagelar. Dengan areal yang sangat luas, kampung Kasepuhan Ciptagelar terbagi menjadi berbagai klaster yang dibatasi dengan hutan dan sungai sehingga memiliki jarak yang cukup jauh satu sama lain. Atas perintah Sesepuh Girang selaku pemerintahan adat, masingmasing klaster harus memiliki komplek leuit, setidaknya satu saung lisung, dan komplek perumahan yang memuat goah di dalamnya. Seluruh warga Kasepuhan Ciptagelar mematuhi aturan tersebut dikarenakan mereka juga mempercayai bahwa adanya ketiga 


\begin{abstract}
bangunan ini akan memenuhi harmoni dari proses pengelolaan padi dan beras sesuai dengan falsafah kehidupan (tilu sapamilu) serta kepercayaan mereka (tatali paranti karuhun). Adanya ketiga jenis bangunan ini dalam tiap klaster menjadikan tiap masyarakat memiliki pasok pangan yang cukup dengan akses yang mudah, sehingga mereka tidak lagi dicemaskan dengan kebutuhan pangan. Hal ini sesuai dengan indikasi kedaulatan pangan dimana satu kelompok masyarakat memiliki pangan yang cukup dan merata.
\end{abstract}

\title{
PENUTUP
}

Desa Kasepuhan Ciptagelar merupakan area yang sangat luas sehingga terdapat beberapa komplek-komplek perumahan yang terpisah dengan jarak yang cukup jauh antara satu komplek dengan komplek lainnya. Meski demikian, dikarenakan ketiga obyek penelitian ini merupakan satu kesatuan yang terintegrasi sehingga tidak bisa dipisahkan, maka ketiganya akan selalu ada di tiap komplek perumahan yang paling kecil dan sepi sekalipun. Hal ini berarti bahwa tiap komplek perumahan atau klaster memiliki setidaknya satu komplek leuit tempat menyimpan padi, satu saung lisung untuk menumbuk padi menjadi beras, dan masing-masing rumah memiliki goah tempat memasak beras menjadi nasi untuk kebutuhan pangan harian. Selain itu, Sesepuh Girang selaku pemerintahan adat memiliki peran untuk memastikan bahwa aturan nenek moyang ini terus dijalankan. Tidak hanya itu saja, Sesepuh Girang juga yang memutuskan di mana lahan yang diperbolehkan untuk dibuka untuk mendirikan ketiga jenis bangunan ini agar tidak melanggar aturan nenek moyang dengan mendirikan bangunan di atas tanah terlarang. Dengan demikian pemerintahan adat mengetahui dengan pasti lokasi tiap bangunan di setiap klaster.

Adanya ketiga jenis bangunan ini di dalam tiap klaster menjadikan klaster-klaster ini berdaulat dalam hal pangan dimana mereka masing-masing memiliki simpanan padi yang cukup, fasilitas menumbuk padi, dan fasilitas memasak nasi. Dengan letak leuit, saung lisung, dan goah yang strategis maka terdapat pembagian sumber pangan yang merata di seluruh Kampung Gede. Sementara dengan informasi yang dimiliki oleh pemerintahan adat terkait letak dan posisi tiap klaster, Sesepuh Girang beserta jajarannya mampu bertindak cepat saat salah satu klaster membutuhkan bantuan dalam bidang pangan dan mampu mengantisipasi masalah sebelum terjadi kelaparan. Dengan demikian masyarakat ini telah memenuhi persyaratan kategori masyarakat yang telah mencapai kedaulatan pangan, yakni setiap penduduk memiliki akses fisik dan ekonomi terhadap pangan; serta kemampuan pemerintah dalam mengantisipasi dan bertindak jika ada kerawanan pangan. 
Sebagai masyarakat tradisional yang masih menerapkan aturan leluhur, terutama dalam pertanian, masyarakat Sunda Kasepuhan Ciptagelar telah mencapai kedaulatan pangan. Dalam penelitian kali ini telah dilakukan pengamatan dan analisis bagaimana tepatnya masyarakat ini mencapai kedaulatan pangan dilihat dari sisi penggunaan bangunan tradisional dalam proses pengolahan padi dan beras, yakni leuit, saung lisung, dan goah. Hasil penelitian menunjukkan bahwa terdapat hubungan pola bangunan leuit, saung lisung, dan goah dalam budaya bertani masyarakat Sunda Kasepuhan Ciptagelar sebagai upaya menjaga ketahanan pangan.

\section{PENUTUP}

Hasil dari penelitian ini menunjukkan bahwa desain kostum dan atribut pada kelima Superhero "Panca Satria" menunjukkan representasi nilai-nilai bela negara. Setiap karakter mewakili satu nilai yang tercermin dalam pemaknaan konotasi yang beroperasi di dalamnya. Kostum superhero berbasis kearifan lokal seperti hijab, batik, bunga kamboja, gada, dan keahlian pencak silat yang disuguhkan dalam desain fashion dan atribut karakter merupakan ide cemerlang seorang desainer. Hal tersebut dapat membuka wacana bahwa kearifan lokal memiliki peluang dan dapat diangkat pada tren masa depan yaitu berupa desain kostum dan atribut superhero yang menarik bagi anak-anak. Sehingga, edukasi tentang nilai-nilai bela negara kepada anak dapat dilakukan secara efektif. Penciptaan desain fashion dan atribut khas Indonesia seperti ini merupakan galian ilmu yang harus terus-menerus dikembangkan. Hal tersebut sebagai bentuk upaya pelestarian budaya Indonesia melalui cara yang menarik bagi anak-anak usia dini, sehingga edukasi tentang nilai-nilai bela negara bukan hanya dapat dipelajari oleh orang dewasa saja, namun juga dapat diketahui oleh anak-anak sejak dini. Urgensi ini bukan hanya untuk kepentingan desainer semata, melainkan menjadi kewajiban moral seorang desainer untuk turut serta menanamkan nasionalisme kepada anak Indonesia agar mencintai Indonesia sejak dini melalui karya-karya desain karakter superhero asli Indonesia.

\section{DAFTAR PUSTAKA}


Ambayoen, Mas Ayu, Bayu Adi Kusuma, dan Resya Eka Pratiwi. (2018). Communication Strategy of Kasepuhan Sinar Resmi Community In Maintaining Local Varieties For Strengthening Leuit (Village Barns). Jurnal Agricultural Socio-Economics, 18 (1), 30-36.

Asep. (2000). Kasatuan Adat Banten Kidul: Dinamika Masyarakat dan Budaya Sunda Kasepuhan di Kawasan Gunung Halimun Jawa Barat. Tesis Program Pascasarjana, Institut Pertanian Bogor, Bogor.

Ariesa, Y. (2019). Faktor-Faktor Yang Mempengaruhi Ketahanan Pangan Dengan Menggunakan Analisis Faktor Konfirmatori. Jurnal Abdi Ilmu, 12 (1), 8-18.

Creswell, J.W., dan C.N. Poth (2016). Qualitative Inquiry and Research Design: Choosing Among Five Approaches. Sage publications.

Elizabeth, Roosganda. (2011). Strategi Pencapaian Diversifikasi dan Kemandirian Pangan: Antara Harapan dan Kenyataan. Jurnal Iptek Tanaman Pangan, 6 (2), 230-242.

Manan, Abdul. (2015). Metode Etnografi dalam Dimensi Metodologis Ilmu Sosial dan Humaniora. Banda Aceh: Lhee Sagoe Press.

Nuryanto. (2011). Fungsi Dan Makna Pawon Pada Arsitektur Rumah Tradisional Masyarakat Sunda. Proseding The Local Tripod Akrab Lingkungan, Kearifan Lokal, Dan Kemandirian, 164-170.

Rahmawati, Rita., dan D.E.I Gentini (2008). Pengetahuan Lokal Masyarakat Adat Kasepuhan : Adaptasi, Konflik, dan Dinamika Sosio-Ekologis. Sodality: Jurnal Transdisiplin Sosiologi, Komunikasi, dan Ekologi Manusia, 151-190.

Rayadie, Ahmad. (2017, 24 Maret). Tradisi Ciptagelar di Sukabumi Mampu Pertahankan Kampung Adat. Pesan disampaikan dalam https://www.pikiran-rakyat.com/jawabarat/pr-01277088/semarangku?page $=2$

Sabarguna, Boy. S. (2005). Analisis Data Pada Penelitian Kualitatif. Jakarta: Penerbit Universitas Indonesia.

Seamon, D., dan Sowers, J. (2008). Place and placelessness (1976): Edward Relph. Key Texts In Human Geography, 43-52

Sumardjo, Jakob. (2015). Sunda Pola Rasionalitas Budaya. Bandung: Penerbit Kelir. 